\title{
Maija Krekle
}

\section{leraksti Misiṇa bibliotēkas grāmatās - laikmeta un cilvēku raksturotāji}

Atslēgvārdi: Jānis Misiņš, latviešu literāti, Kārlis Egle, bibliotēka, veltījumi.

Misiṇa bibliotēkā glabājas milzīgs un joprojām neizskaitīts daudzums grāmatu ar dažādiem ierakstiem. Mans pētījums veltīts, manuprāt, interesantākajiem no tiem - veltijjuma ierakstiem.

Misiņa bibliotēka arvien ir bijusi daudzu latviešu kultūras cilvēku pulcēšanās vieta. Jau no tiem senajiem laikiem, kad Jānis Misiņš (18621945) no Lejasciema pārnāca dzīvot un strādāt uz Rīgu, viņa grāmatu krātuvē pulcējās latviešu rakstnieki, kas te atrada patiesi aizraujošas literārās bagātības un ieinteresētu un erudītu sarunu biedru - šo bagātību saimnieku. Misiņa veikalā grāmatu krātuvē Daugavmalā, Kārḷa ielā, tāpat mazāk zināmajā Pārdaugavas veikaliṇā Jelgavas ielā bieži ciemiṇi bija dzejnieki Vilis Plūdons (1874-1940), Jānis Poruks (1871-1911), literatūras pētnieks Teodors Zeiferts (1865-1929), rakstnieks Augusts Deglavs (1862-1922), kā arī citi latviešu kultūras darbinieki.

Viṇi papildināja Misiṇa grāmatu krātuvi ar savām jaunizdotajām grāmatām un ierakstīja tajās sirsnīgus veltījumus, augsti novērtējot arī Misiña grāmatu krājēja darbu. "Mūsu grāmattēvs", "godātais latviešu literatūras krājējs" ir patiesi dziḷas cieņas pilni vārdi. Vilis Plūdons 1910. gadā izdotajā "Latvju literatūras vēsturē" ierakstījis: "Savam mịḷajam biedrim J. Misiṇam Sarakstītājs."1 1911. gadā grāmatā "Fantāzija

1 Ieraksts grāmatā: Plūdons, V. 1910. Latvju literatūras vēsture. Jelgava: L. Neimans. Inv. Nr. 3571. par puķēm” dzejnieks veltījumu ir paplašinājis: "Savam mīlajam, labajam biedrim, mūsu grāmattēvam J. Misinam."2 (1) Par godāto latviešu literatūras krājēju, romāna "Rīga" pirmizdevumu dāvinot, Misinu dēvē Augusts Deglavs.

Pēc Pirmā pasaules kara, kad bibliotēka atradās divos trīsistabu dzīvokḷos Skolas ielā 25, gandrīz katrs latvju rakstnieks neatkarīgi no idejiskās un reliğiskās pārliecības uzskatīja par pienākumu savus jauniznākušos daiḷdarbus dāvāt Misiņam, labi zinot, ka šì uzcītīgā cilvēka izveidotajā pilnīgākajā latviešu grāmatu krātuvē tās tiks saglabātas uz mūžiem. Veltījuma ierakstos epiteti ir visdažādākie: "manam sirdsdraugam" (Ivande Kaija; 1876-1942)3 "l,oti cienītam" vai arī "ḷoti godātam bibliofilam" (Viktors Eglītis; 1877-1945)4, "mīḷajam Jānim Misiņam" (Viktors Eglītis ${ }^{5}$ ), "latvju literatūras mecenātam” (Jānis Roze; 1878-1942) ${ }^{6}$. Proletariāta rakstnieks Leons Paegle (1890-1926) visās četrās dāvātajās grāmatās gan rakstījis lakoniski: "Misiņa kgm."

Kā īpaši ievērības cienīgus gribētos atzīmēt sešus veltījumus. Vispirms jau sirmā Kaudzītes

2 Ieraksts grāmatā: Plūdons, V. 1911. Fantāzija par pukeèm. Rīga: Saulīt-Melder apgāds. Inv. Nr. 21.718.

3 Ieraksts grāmatā: Kaija, I. 1921. Sfinksa. Rīga: Valters un Rapa. Inv. Nr. 174319.

4 Ieraksts grāmatā: Eglītis, V. 1921. Kopoti raksti. 17. sēj. Rīga: Leta. Inv. Nr. 167650.

5 Ieraksts grāmatā: Eglītis, V. 1921. Dvēseles varā. Rīga: Leta. Inv. Nr. 170345.

6 Ieraksts grāmatā: Roze, J. 1924. Latviešu stenografija. 4. izd. Rīga: Valters un Rapa. Inv. Nr. 119948. 
Matīsa (1848-1926) "sadraudzīgais" veltījums "Jauno "Mērnieku laiku"” pirmizdevumā 1924. gadā: “A.c. J. Misiņa kungam sadraudzīgi no sarakstītāja."7

1927. gadā Tirzmaliete (1876-1942) savu veltījumu Kopotu rakstu 1. sējumā izteikusi viedās dzejas rindās:

Kas savu dvēseli vēro,

Tas mācās likteņus -

Un mīlējot mūžìgi daiḷo

Ver gaismas avotus. ${ }^{8}$

Izcilais latviešu komponists Jāzeps Vītols (1863-1948) 1935. gada 5. februārī dāvinājis J. Misiņam grāmatu "J. Vītols. Kopotas dziesmas" (kas iznākusi jau 1933. gadā) ar šādu ierakstu: "Mīḷajam kaimiņam J. Misiņa kgm atpūtas brīžiem J. Vītols 5.II 1935." Jācer, ka erudītais grāmatnieks izmantoja šo ieteikumu, jo jaunībā bija piedalījies III Vispārējos latviešu dziesmu svētkos (toreiz - Latviešu trešie vispārīgie dziedāšanas svētki) un notis drusku pazina, lai arī savas mịlākās dziesmas pierakstījumu notīs 20. gadsimta sākumā uzticēja Emīlam Dārziņam...

Kad J. Misiņš lielā vecuma dēḷ (viņam bija sešdesmit trīs...) savu bibliotēku nodeva Rīgas pilsētai un par Misiņa bibliotēkas pārzini izvēlējās Kārli Egli (1887-1974), ne Egle, ne arī citi bibliotēkas darbinieki turpmākajos gados neaizmirsa savu patronu apsveikt lielākās un mazākās dzīves jubilejās. Dziḷa cieņa un godbijība viņiem allaž bijusi pret grāmatu krātuves dibinātāju un izcilo latviešu kultūras darbinieku. Rabindranata Tagores Rakstu 2. sējumā, kas iznācis 1936. gadā, atrodams šāds ieraksts: "Mīḷajam J. Misiņam 1936. gada 1. martā. Tulkotājs K. Egle."10 Savukārt Johana Volfganga Gētes "Romas elēǵiju” 1941. gada izdevumā ir veltījums:

7 Ieraksts grāmatā: Kaudzīte, M. 1924. Jaunie "Mērnieku laiki". 1. d. Cēsis-Rīga: O. Jēpe. Inv. Nr. 245202.

9 Ieraksts grāmatā: Vītols, J. 1933. Kopotas dziesmas jauktiem, vìru un sievu koriem a capella. Rīga: Latviešu skan,ražu kopa. Inv. Nr. 84712.

10 Ieraksts grāmatā: Tagore, R. 1936. Raksti. 2. sēj., 2. iesp. Rīga: A. Gulbis. Inv. Nr. 84314.
"Bibliofilam Jānim Misiņam 80. dzimšanas dienā 1942. gada 25. aprīî̀ K. Egle un pārējie Misin,a bibliotēkas darbinieki." 11

Desmit mēnešus pirms nāves, kara pēdējā vasarā, J. Misiņš saṇēma divdesmittrīsgadīgā autora Alvara Zaiga (Valta Grēviņa; 1921-1961) grāmatu "Māņi” (1944). Jaunais cilvēks tajā ierakstījis: "Grāmatniecības krīvam Misiṇtēvam autors 1944. g. jūnijā."12

Cilvēks aiziet, viņa darbs paliek. Misiņa bibliotēkas darbinieki nenogurdināmā K. Egles vadībā turpināja attīstīt pilnīgāko latviešu grāmatu krātuvi, arvien jauni un jauni lasītāji iestaigāja ceḷu uz mājīgajām Torņa ielas 3/5 telpām. Jauna rakstnieku paaudze atstāja savas esamības liecības, biežs viesis bibliotēkā bija Aleksandrs Čaks (1901-1950). Latviešu literāti pamazām izgāja plašajā pasaulē, tomēr neaizmirstot Misina bibliotēku, sarunvalodā sauktu vienkārši par Misiniem. Jānis Veselis (1896-1962), piemēram, dāvinot sava darba "Dievu gulta" tulkojumu čehu valodā (1930), ieraksta: "Jān,a Misiņa bibliotēkai par piemiņu no Jāṇa Veseḷa. 2.V.1930.”13

Kad Misiņa bibliotēka pēc Otrā pasaules kara pārcēlās uz arhitekta Augusta Reinberga namu Skolas ielā 3, tā turpināja būt latviskās kultūras centrs par spīti tam, ka K. Egle tika atstādināts no direktora pienākumiem un pati bibliotēka vispirms pievienota jaundibinātajai Latvijas PSR Zinātṇu akadēmijai, bet pēc tam arī tās Fundamentālajai bibliotēkai. Joprojām papildinājās veltījuma ierakstu skaits. Misina bibliotēku mīlējuši un apdzejojuši daudzi rakstnieki un dzejnieki, slavējuši literatūras, teātra un mūzikas zinātnieki, gandrīz visu Latvijas PSR tautas rakstnieku un dzejnieku veltījumus var atrast bibliotēkas grāmatās. Vilis Lācis (1904-1966), parakstoties “Zvejnieka dēla”

11 Ieraksts grāmatā: Gēte, J. V. 1941. Romas elēgiijas. Rīga: Latvju Grāmata. Inv. Nr. 141.846.

12 Ieraksts grāmatā: Grēvin̦š, V. 1944. Māṇi. Rīga: J. Alkšn,a apgāds. Inv. Nr. 144.473.

13 Ieraksts grāmatā: Veselis, J. 1930. Lužko bohu. Praha: Šolc a Šimaček. Inv. Nr. 70.120. 


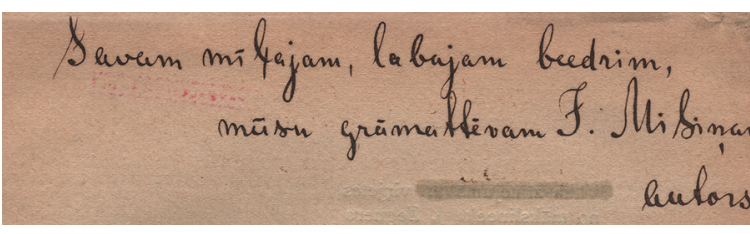

Viḷa Plūdoṇa veltījums Jānim Misinamam

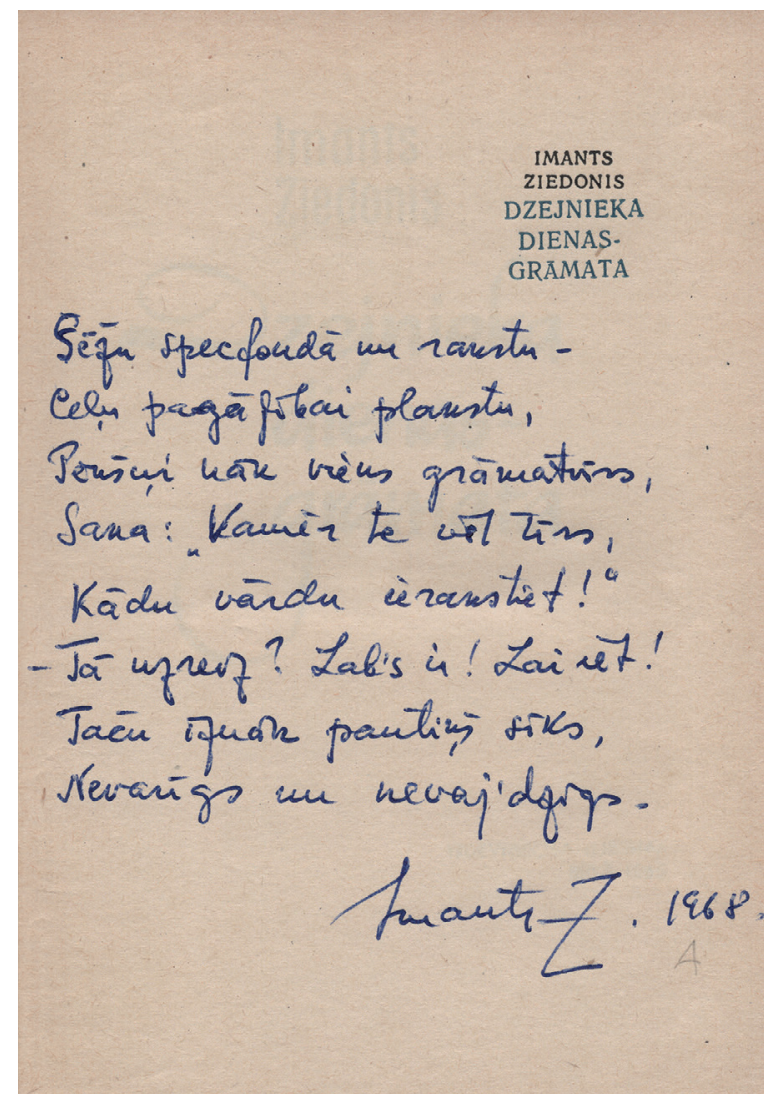

Imanta Ziedoṇa ieraksts “Dzejnieka dienasgrāmatā” tulkojumā igauṇu valodā "Kaluri poeg” (1952), bijis lakonisks: "10.09.1952.: LPSR Zinātņu Akadēmijas Misiņa bibliotēkai."14 Savukārt Imants Ziedonis (1933-2013) 1968. gada pavasarī parāda savu zobgaḷa dabu vairākos dzejojumos, kuri laikam gan nav ietverti nevienos kopotajos rakstos. "Dzejnieka dienasgrāmatā" (1965) viņš ierakstījis:

"Sēžu specfondā un rakstu Cel̦u pagājībai plakstu, Pēkšņi nāk viens grāmatvīrs, Saka: "Kamēr te vēl tīrs, Kādu vārdu ierakstiet!" Tā uzreiz? Labs ir! Lai iet! Taču iznāk pantiņš sīks, Nevarīgs un nevaj'dzīgs.

Imants Z. 1968."15

Savukārt krājumā "Zemes un sapṇu smilts" (1961) atrodama šāda četrrinde:

“Jūs, kas speciālā fondā strādājat no stundas stundā, lai tiek saglabāts kā mīts katrs senais puteklīts.

Imants Z. 1968.”16

Pretenzijas uz mūžību ieraugāmas grāmatas "Sirds dinamīts" (1963) eksemplārā:

"Lielībā un dūšībā gribu ieiet mūžībā, jūs tad arī dūšìgi glabājiet to mūžīgi.

Imants Z. 1968. gada maijā."17

Un ne jau tikai dzejā izpaudies tobrīd trīsdesmitpiecgadīgais kuplmatainais dzejnieks.

14 Ieraksts grāmatā: Lācis, V. 1952. Kaluri poeg. Tallinn: Eesti Riiklik Kirjastus. Inv. Nr. 57-5-73.

15 Ieraksts grāmatā: Ziedonis, I. 1965. Dzejnieka dienasgrāmata. Rīga: Liesma. Inv. Nr. 142-2-65.

16 Ieraksts grāmatā: Ziedonis, I. 1961. Zemes un sapn̨u smilts. Rīga: LVI. Inv. Nr. 197.012.

17 Ieraksts grāmatā: Ziedonis, I. 1963. Sirds dinamīts. Rīga: LVI. Inv. Nr. 211.937. 
Grāmatas "Pa putnu ceḷu” (1957) ierakstā I. Ziedonis taisnojas: "Šì tāda vāja iznāca, tas tāpēc, ka visu laiku bija jāairē un jātura sportsmeniiem līdz. Otrreiz tādā barā nelaidīšos.

I. Ziedonis 1968." 18

Citi kultūras darbinieki ir bijuši daudz nopietnāki. Izcilais grāmatzinātnieks Aleksejs Apīnis (1926-2004) sava darba "Latviešu grāmatniecība” (1977) eksemplārā ierakstījis Misiņus pagodinošas rindas: "Atrasties tādā bibliotēkā šai grāmatai ir liels gods. A. Apinis 1980. g. 19. febr."19

Veltījumi tikuši atstāti arī grāmatās, kas bibliotēkas plauktos nonākušas pēdējos divdesmit sešos gados, kad Misina bibliotēka pārcēlusies uz telpām Rūpniecības ielā 10 un ietilpst Latvijas Universitātes Akadēmiskās bibliotēkas sastāvā.

Literatūrvēsturnieks Ilgonis Bērsons (1931), bibliotēkas lasītājs jau gandrīz septiņdesmit gadu garumā, savā grāmatā "Auseklītis zem āmura un kāškrusta" (2006) raksta: "Misiņa bibliotēka ir svēta vieta: te senči sarunājas ar tagadnes darbarūkiem un nākotnes praviešiem. Pateicībā visiem sirsnīgajiem darbiniekiem Ilgonis Bērsons (lasītājs kopš N gada) 2006.21.06." 20

Mūzikas zinātnieks Arnolds Klotinš (1934), kura darbi mūzikas vēsturē nebūtu tapuši bez Misin, bibliotēkas darbinieku izpalīdzības un bez tās bagātīgā krājuma izmantošanas, grāmatas "Mūzika pēckara staliinismā" (2018) titullapā ierakstījis: "Misiņa Bibliotēkas Saimei pateicībā par palīdzību, padomiem un faktisko līdzdalību grāmatas darināšanā." ${ }^{21}$

Arvien mīla Misina bibliotēka bijusi rakstniekam Zigmundam Skujinam (1926).

18 Ieraksts grāmatā: Ziedonis, I. 1957. Pa putnu ceḷu. Rīga: LVI. Inv. Nr. 336-8-67.

19 Ieraksts grāmatā: Apinis, A. 1977. Latviešu grāmatniecība. Rīga: Liesma. Inv. Nr. 224-5-77.

20 Ieraksts grāmatā: Bērsons, I. 2006. Auseklītis zem āmura un kāškrusta. Rīga: Sol Vita. Inv. Nr. 269049.

21 Ieraksts grāmatā: Klotin̦š, A. 2018. Mūzika pēckara stalinismā: Latvijas mūzikas dzìve un jaunrade 1944-1953. Rīga: LU LFMI. Inv. Nr. 818015928.
Pagaidām pēdējais no viṇa daudzajiem dāvinājumiem ir Milānā izdotais romāna "Miesas krāsas domino" tulkojums itâlu valodā "Come tessere di un domino" (2017), kura titullapā autors ierakstījis: "Ar prieku šo grāmatu dāvinu savai mīlajai Misiņa bibliotēkai. Zigmunds Skujiňš." 22

Bibliotēkai visvairāk grāmatu dāvinājuši un savus autogrāfus dažādos laikos atstājuši tās lasītāji un draugi (minu alfabēta secībā): Arnolds Auziņš (1931), Marta Bārbale (1933-2003), Ilgonis Bērsons, brāḷi Antons (1876-1971) un Pēteris (1881-1956) Birkerti, Saulvedis Cimermanis (1929), Kārlis Dravin̄̌s (1901-1991), Indra Gubiña (1927-2017), Uldis Ģērmanis (1915-1997), Arturs Heniņš (1932-2014; Misinus nosaucis par iedvesmas bibliotēku), Andrejs Irbe (1924-2004), Astrīde (1926-2015) un Ivars (1927-1992) Ivaski, Jānis Alberts Jansons (1892-1971), Jānis Kalninšs (19222000), Anda Kubuliṇa (1942), Kārlis Krūza (1884-1960), Janīna Kursīte (1952), Jānis Liepiņš (1930), Milda Losberga (1923-2011), Vitauts Lū̄ēens (1937-2010), Lalita Muižniece (1935), Gunārs Selga (1929-1986), Zigmunds Skujiņš, Ojārs Spārītis (1955), Heinrihs Strods (1925-2012), Jeronīms Stulpāns (1931-1981), Tālivaldis Treicis (1939-2008), Rihards Treijs (1931-2013), Māra Zālìte (1952), Dzidra Zeberina (1923-2016), Teodors Zeiferts, Imants Ziedonis...

Ir vēl otra ierakstu grupa. Tie ir veltīti nevis bibliotēkai, bet kādam noteiktam cilvēkam. Gadu gaitā Misiņa bibliotēkā nonākušas grāmatas no daudzām personīgajām bibliotēkām. Daži, mūžam uz galu ejot, ir grāmatas atdāvinājuši, citi atdevuši kā vairs nevajadzīgas. Pirmajos pēckara gados, kā zināms, bija daudz "bezsaimnieka" mantu, kas, paldies Dievam un K. Eglem, nevis tika iznīcinātas, bet nogūla bibliotēkas plauktos. Pēc Latvijas neatkarības atgūšanas daudz grāmatu dāvinājumu nācis no trimdas tautiešiem. Tā bibliotēkā atrodas

22 Ieraksts grāmatā: Skujinšs, Z. 2017. Come tessere di un domino. Milano: Iperborea. Inv. Nr. 819000038. 
gandrīz visas Veltas Tomas (1912-1999) grāmatas ar latviešu (padomju) rakstnieku veltijumiem. Joprojām bibliotēka saņem grāmatas ar ierakstiem, kurus autori - draugi un kolēǵi - ir dāvinājuši cits citam. L,oti bagātu ierakstu klāstu ar veltījumiem dzejniecei Ārijai Elksnei (1928-1984) bibliotēka ieguva 2018. gada vasarā, kad arhitekts Uldis Bērziņš nodeva Misiņiem savas ğimenes bibliotēku.

Noslēgumā neliels ieskats dažos likten,os un raksturos. Vērojot rokrakstus, mēs mēginām izprast cilvēkus un vinuu attiecības. Sirsnīgais veltījums no Augusta Saulieša rāda, ka uzruna "mīlais biedri" bijusi visai izplatīta starp kolēǵiem - rakstniekiem: "Savam mịlajam biedrim Plūdonim - A. Sauliets. Pavasarī 1910." 23

Traǵiskais Jāņa Ziemel̦nieka (1897-1930) mūža gals jau nojaušams septinuus gadus pirms vinna nāves - veltījumā bijušajai skolotājai Zelmai Grīnbergai, dāvinot savu pirmo dzejoḷu krājumu "Nezināmai" (1923): "Labai neaizmirstamai skolotajai Zelmai Grinberg gaišai atminnai. Rīgā, 5.VIII 23. J. Ziemel̦nieks." Ieraksts grāmatā vēl nav tik skumjš kā klāt pieliktā vēstulīte, kurā dzejnieks atzīstas savā nespējā dzīvot bez opiuma. ${ }^{24} 3$

Kā brīniškīigs mākslas darbs gan grafiski, gan saturiski ir Jāna Sudrabkalna (1894-1975) poētiskais veltījums Ā. Elksnei grāmatā "Osis logā" (1969): "Kad es domāju par Āriju Elksni, domāju par to, cik patiesīgi, vienkārši un dziḷi, neatvairāmi pievilcīgi vina ietver savās vārsmās dzīvi un sapnuus, redzu iztālēm burvīgu sievieti, dzirdu dīvaini mulsinošu balsi un pēkšņi atrodos kopā ar vinuu un vinas meiteni zem viena lietussarga, izstiepju roku pret ošiem, pīlādžiem, kḷavām un liepām un klusā balsī saku: “Ārija, esiet

23 Ieraksts grāmatā: Saulietis, A. 1910. Varavikssne. Rīga: Varavīksna. Inv. Nr. 136.601.

24 Ieraksts grāmatā: Ziemeḷnieks, J. 1923. Nezināmai. Rīga: Lapsene. Inv. Nr. 116.878. sveicināta! Jānis Sudrabkalns Svētupes Sprundās 1969. gada Līgo svētku dienā.""'25 4

Dzejniecei Ā. Elksnei draudzīga humora pilnas rindas veltījis Gunārs Priede (1928-2000), kā dāvanu pasniedzot savas "Piecas lugas" (1973): “.. jauneklītim, redz, nepatīkot Ārijas Elksnes dzejoḷi... (325. lpp.) Ārijai, pateicībā, ka viṇa ne pret līdzautorību protestēja, ne (kā daži cerēja) skrēja ārā no zāles - Gunārs 17.11.73. "Aivaru gaidot" pirmizrādē." 26 Tie, kas redzējuši šo izrādi, zina, par ko ir stāsts. Ne jau katrs varēja pieñemt draisko formu un "svētuma apgānīšanu".

Vēl viens izsmelıšs Ā. Elksnes raksturojums, ko devis I. Ziedonis, rakstot veltījumu grāmatā "Poēma par pienu" (1977): "Ārijai, neeksotiskai, neekstravagantai, nepārmodernai, netranscendentālai, neimpresionistiskai, neekspresionistiskai, nepuritāniskai, neekstrasensuālpatologiskai, nespīdoliskai, nelaimdotiskai, nekibernētiskai, nerevolucionārai, sievišk,īgi izturētai, pašveidīgi realizētai būtnei - būtnis Imants Z 19.II 1978."27

Citā poēmas eksemplārā atrodamas dzejnieka drūmās pārdomas par Latvijas govju likteni. Diezgan pravietiski izrādījušies vārdi "brūno nomaiņas laikā ar melnraibajām; nevar gan vēl zināt, kā tālāk būs arī ar tām". ${ }^{28}$

Savukārt 1974. gadā iznākušās "Epifānijas” I. Ziedonis nākamajā gadā dāvina V. Tomai ar šādu ierakstu: "Vējam dod siltas pēdas, rasai dos vēja tiesu, ūdenim skrējējam l̦auj tecēt spilvenā. (jo vairāk jauc, jo skaidrāk paliek) Veltai - Imants 1975. Rīgā."29

Akrostihu - veltījumu dzejniekam Andrejam Eglītim (1912-2006) 85. jubilejā

25 Sudrabkalns, J. Ieraksts grāmatā: Sudrabkalns, J. 1969. Osis logā. Rīga: Liesma. Inv. Nr. 233-6-69.

26 Ieraksts grāmatā: Priede, G. 1973. Piecas lugas. Rīga: Liesma. Inv. Nr. 314-2-73.

27 Ieraksts grāmatā: Ziedonis, I. 1977. Poēma par pienu. Rìga: Liesma. Inv. Nr. 21-9-78.

28 Ieraksts grāmatā: Ziedonis, I. 1977. Poēma par pienu. Rīga: Liesma. Inv. Nr. 4-5-78.

29 Ieraksts grāmatā: Ziedonis, I. 1974. Epifānijas. Rīga: Liesma. Inv. Nr. 48-9-75. 


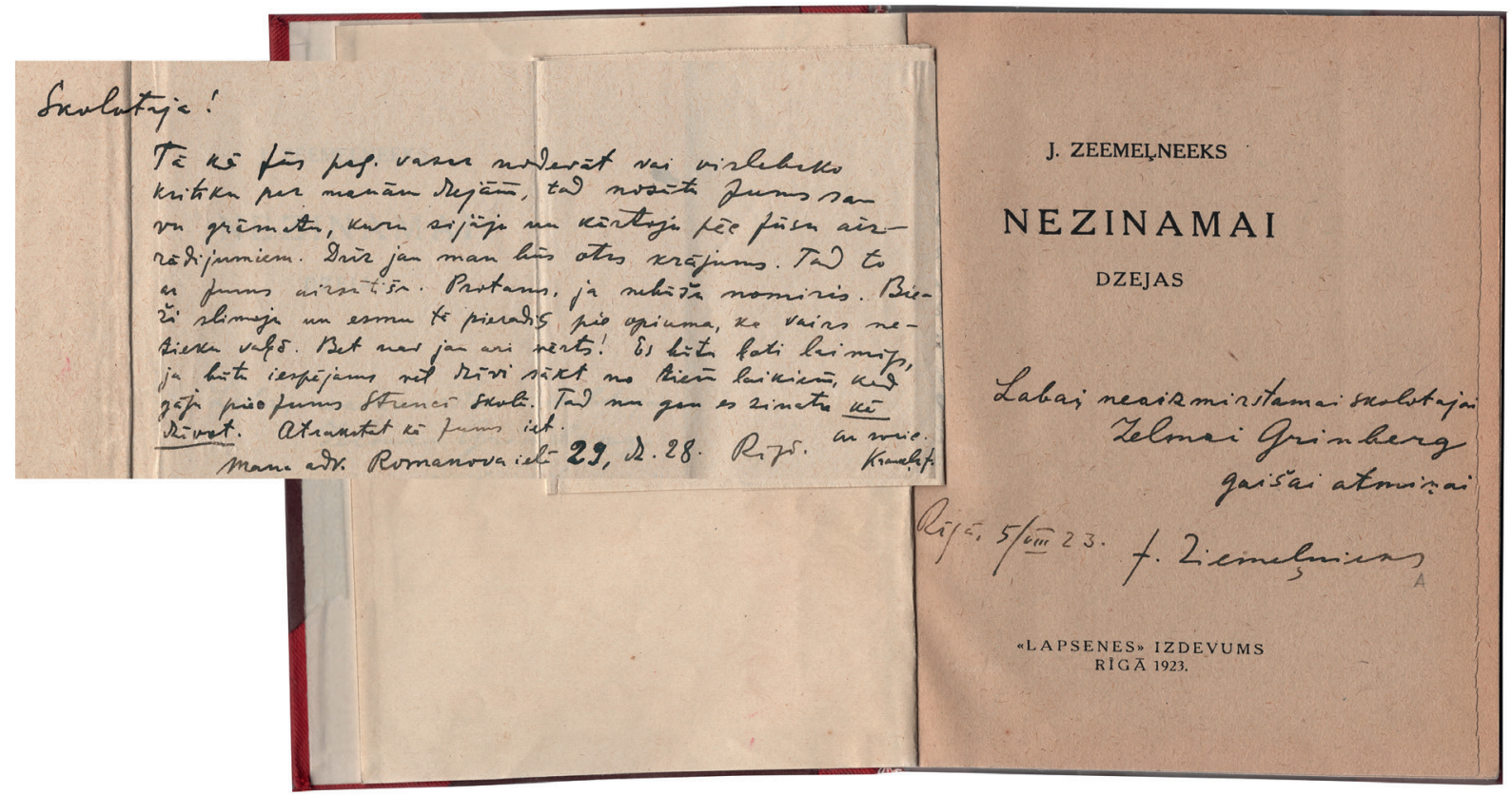

(3) Jāṇa Ziemeḷnieka veltījuma ieraksts un vēstule skolotājai Zelmai Grīnbergai

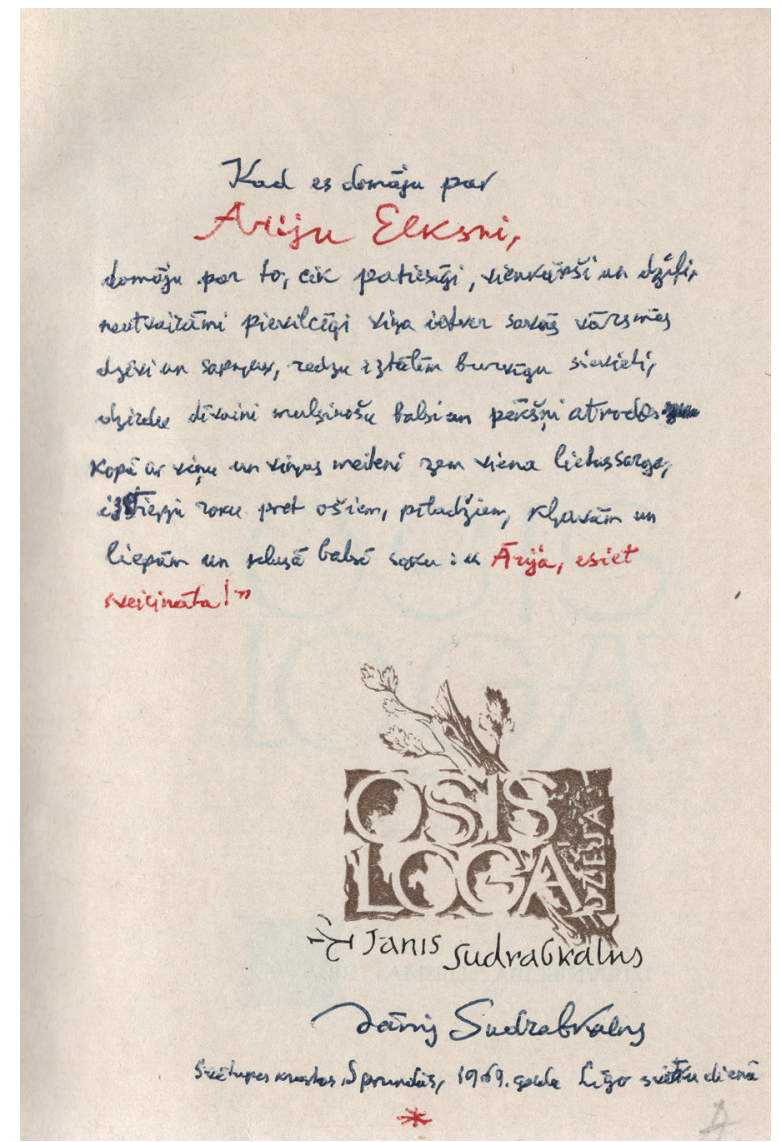

Jāṇa Sudrabkalna veltijums Ārijai Elksnei 
I. Ziedonis ierakstījis dāvātajā savu Rakstu 4. sējumā (1995):

Augstums pie augstuma aug. Negaiss pie negaisiem mācās.

Debesīs zīmes Dievs liek,

Retais tās izlasīt prot.

Ezeros lilijas mirdz, un

Jūrā mirdz vientuḷa bura;

Atkal un atkal Dievs teic:

"Mīlestības par maz".

Eṇgeli runā ar mums -

Gaudenie nedzird, ne gudrie.

Labi, ka ir kāds, kas dzird -

Īsteni gājis Tavs ceḷš.

Ticības tālumu pilns,

Ieraudzìt tur Tev bij lemts

Māti un mūs. Un trīs zvaigznes. ${ }^{30}$

Ojāra Vācieša (1933-1983) draudzībai ar V. Tomu raksturīga pilnīga uzticēšanās un pašironijas pilna atklātība: "Mīlāa Velta, kādas nu tās stundas ir. N̦em par labu. Ojārs. 25.XII 74."31 Grāmatas "Tās dienas acīm" otrajā izdevumā (1975) dzejnieks raksta: "Veltin, nepietiek ar to, ka izdod otru reizi [..] pirmā (un - pati pirmā, ko sūtīju), tātad ir noklīdusi. Ojārs. 21.II 76. g. Rīgā."32 5

I. Ziedonis savas izlases virsrakstu "Ar tikko grieztu k,eizarkroni rokā” (1979) radoši papildina, pierakstot klāt: “.. uz debesīm kāp Ojārs Vācietis kokā. To apstiprinu.

I. Ziedonis." 33

Unikāls ir I. Ziedon,a dzeju krājuma "Re, kā" (1981) eksemplārs, kas vairāku dzejnieku dāvināts Kanādas viešnai V. Tomai. Ziedonis apdzejojis katru no četriem kolēǵiem (Māri Čaklo, Liju Brīdaku, Māru Zālīti, Olgu Lisovsku), kuri kopā ar viņu viesojas pie dzejnieces Dubultu jaunrades namā:

31 Ieraksts grāmatā: Vācietis, O. 1974. Visāda garuma stundas. Rīga: Liesma. Inv. Nr. 177-8-74.

32 Ieraksts grāmatā: Vācietis, O. 1975. Tās dienas acīm. Rìga: Liesma. Inv. Nr. 000049745.

33 Ieraksts grāmatā: Ziedonis, I. 1979. Ar tikko grieztu keizarkroni rokā. Rīga: Liesma. Inv. Nr. 192-1-79.

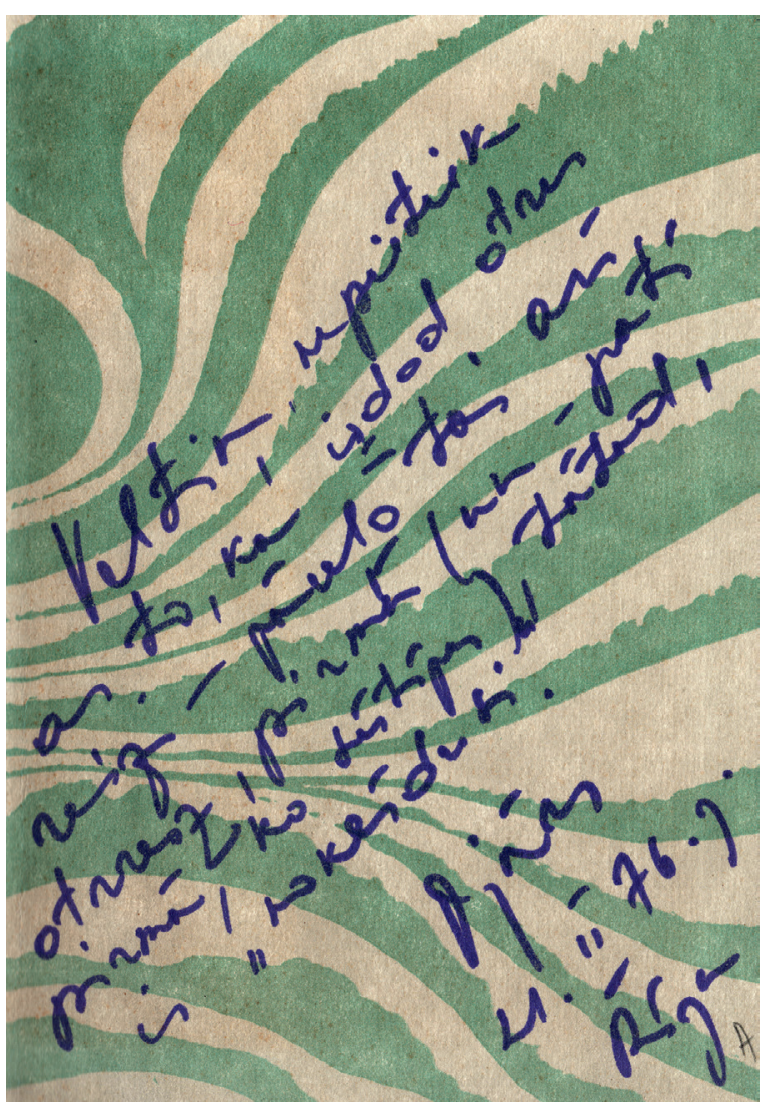

Ojāra Vācieša veltijums Veltai Tomai 
"kā dialektikai tik trijai

man allaž gribas ticēt Lijai

kā spriedumam, kas līst pārpārim

es mērḳtiecīgi ticu Mārim

jo notiek l,oti smalkas talkas

pie jaunpieolgas, Jaunpiebalgas

tā zālìtei vai citam lakstam

mēs māriski uz laimi rakstām

ar Veltu, viedo saim- un -nieci

mēs ziedojam

met ziedu pieci: Imants, Māris, Lija, Māra,

Olga 1981. gada 4. novembrī Dubultos." 34

V. Tomas mājās Kanādā top šāds I. Ziedoṇa veltījumieraksts krājumā "Ceḷmallapas” (1983): "Pie Veltas nerunāju faktos: jo gari tup te visos kaktos. Veltas mājā Imants 1983. augustā." 35

No iepriekšējiem ierakstiem varēja just latviešu rakstnieku draudzības saišu dziḷumu un stiprumu. Gribētos sniegt arī nopietnu kolegialitātes piemēru, kas pauž patiesu cieņu pret darbabiedru un raksturo gan dāvinātāju, gan saṇēmēju. Šajās domās patiesi ir vērts ieklausīties. Literatūrzinātniece Janīna Kursīte raksta veltījumu kolēgei Verai Vāverei (1929) grāmatā "Latviešu dzejas versifikācija 20. gs. sākumā, 1900-1919" (1988): "Paldies par to, ka Jūs neškirirojat cilvēkus savējos un svešajos, un nevērtējat pēc regālijām, pakāpēm un iztērētā glaimu daudzuma. Varbūt tikai šādi veidotā augsnē var strādāt dažādos virzienos un tomēr - vēlēt cits citam labu un cienìt otru. Janīna 1988.3.02.”36

Ne tikai draudzību un cieņu, bet arī no citiem rūpīgi slēptu mīlestību atspoguḷo veltījuma ieraksti. Garš un tumšmatains latviešu dzejnieks raksta skaistai un talantīgai latviešu dzejniecei: “.. Vecrīgas sniegputeni atceroties, klusā

34 Ieraksts grāmatā: Ziedonis, I. 1981. Re, kā. Rīga: Liesma. Inv. Nr. 260-12-81.

35 Ieraksts grāmatā: Ziedonis, I. 1983. Cel̦mallapas. Rìga: Liesma. Inv. Nr. 170-7-83.

36 Ieraksts grāmatā: Kursīte, J. 1988. Latviešu dzejas versifikācija 20. gs. sākumā, 1900-1919. Rīga:

Zinātne. Inv. Nr. 228148. mīlestībā - Autors. Rīgā, 1960. gada 16. janvārī." ${ }^{37}$ Arvīda Skalbes (1922-2002) mazā dzeju grāmatiņa "Sūrābele" (1959) acīmredzami ilgi glabājusi Ā. Elksnes skumjā mīlas stāsta noslēpumu. Varbūt katru nejaušo tikšanos ar mīlēto cilvēku viņa atzīmējusi ar maza ziediņa ievietošanu starp krājuma lapām un dzejnieka matu cirta garus gadus atgādinājusi par to, kas varēja būt, bet nebija...

Mainās laiki, mainās cilvēki. Atmiņas par tiem paliek gan drukātajā, gan arī rakstītajā tekstā. Neaptverami bagāts ir Misiña bibliotēkas ierakstu krājums, diemžēl tas vēl joprojām nav pienācīgi novērtēts. Veltījumu ierakstiem Misiņa bibliotēkas grāmatās ir milzīga kultūrvēsturiska vērtība, kas mums visiem būtu jāapzinās un ar ko Latvijas Universitātes Akadēmiskajai bibliotēkai būtu patiesi jālepojas.

37 Ieraksts grāmatā: Skalbe, A. 1959. Sūrābele. Rīga: LVI. Inv. Nr. 190.943. 